\title{
Is Higher Education Internationalizing In Turkey? ${ }^{6}$
}

\author{
Leyla Yilmaz Findik, PhD \\ Hacettepe University, Turkey
}

doi: 10.19044/esj.2016.v12n13p295 URL:http://dx.doi.org/10.19044/esj.2016.v12n13p295

\begin{abstract}
European countries has undergone many reforms and strategies based on Bologna Process objectives to become key players in this global knowledge network. This internationalization phenomenon has affected various aspects of Turkish higher education system and Turkey set an agenda to benefit from this international environment and attract foreign students. The main aim of the study is to discuss internationalization in higher education and review of the present status of student mobility in higher education in Turkey after the launch of Bologna Process. The study will provide a picture of internationalizing and mobility in higher education in Turkey to address strategic questions related to the future of higher education in Turkey, and to discuss in detail with the aim of shedding light on new planning. The research was structured as a descriptive study and used secondary data received from Council of Higher Education (CoHE) published on the web site as well as international documents and reports. According to the findings of the study, it is impossible at that moment to report accurately that much progress has been made on internationalizing in higher education in Turkey.
\end{abstract}

Keywords: Bologna Process, internationalizing, student mobility, Turkish higher education

\section{Introduction}

Internationalization has been high on European higher education agenda since Bologna Process launched in 1999 and a stressed issue in all communiques of Bologna Process. Internationalization is defined as "the process of integrating an international, intercultural, or global dimension into the purpose, functions and delivery of post-secondary education" (Knight, 2003). Internationalization tends to address an increase of international activities (Teichler, 2009) and it is generally acknowledged as a

6 This study has been presented at International Congress on New Trends in Higher Education: Keeping up with the Change, on 12-13 April, 2016, in İstanbul, Turkey. 
crucial tool which offers benefits to students, staff, higher education institutions and countries (Eurydice, 2015). Higher education internationalization seems a process that involves joining various spheres of society's activities at the regional or global levels, physical mobility, academic cooperation and academic knowledge transfer and international education (Altbach, Reisberg \& Rumbley, 2009; Karveliene, 2014; Teichler, 2009). The aim of internationalizes higher education is to provide qualified education to students of tomorrow. Internationalization enables to generate the skills required in today's world of global knowledge and technology, encourage strategic thinking and innovation, offer advantages in modernizing pedagogy and develop new approaches. Furthermore, with the infusion of internationalization in higher education, students and academicians gains a greater awareness of global issues and how education operates worldwide (Henard, Diamond \& Roseveare, 2012).

Internationalization has thus many facets and includes various forms of activities (Altbach, Reisberg \& Rumbley, 2009; Frolich \& Vega, 2005; Wachter, 2008). Mobility mainly student mobility as the main tool of internationalizing remains the most visible. Mobility of students has become the most frequently discussed theme (De Wit, 2010; Kehm and Teicher, 2007) since the mobility was declared as one of the core elements of the Bologna process to "develop international cooperation between individuals and institutions, to enhance the quality of higher education and research and to create opportunities for personal growth" (London Comminique, 2007). Mobility allows students to acquire crucial competences and skills needed to compete in the global labor market, as well as help staff to gain new ideas, methods and skills and develop institutional relationships (Eurydice, 2015).

The rate of international and foreign students in Europe seems to have increased 3-7\% in the last decades (Teichler, 2009). Operating in internationalization has an important impact on missions, planning and practices of higher education systems. It is expected from the universities to take an active part in European Union education programs as well as in regional and thematic European university networks (Aittola, Kiviniemi, Honkimaki, Muhonen, Huusko and Ursin, 2009). Mobility phenomenon forces higher education institutions to learn and adapt their management, services and administration procedures (Eurydice, 2015). So many European countries has undergone many reforms and strategies based on Bologna Process objectives to become a key players in this global knowledge network. Of course this internationalization phenomenon has affected various aspects of Turkish higher education system and Turkey set an agenda to benefit from this international phenome and attract foreign students.

Turkey agreed to develop and implement strategies related to internationalization and mobility at the EHEA Ministerial Conference in 
Bucharest in 2012. Turkey reports to allocate a specific budget and provide additional incentives for internationalization activities. Turkey is also one of the countries which have set targets to increase the number of foreign students as Turkey has only $1 \%$ of all tertiary students population enrolled abroad in 2011/2012. After the 2012 Mobility Strategy 51-75\% of the higher education institutions in Turkey claim that they have adopted internationalization strategies and are actively involved in internationalization activities (Eurydice, 2015). These attempts for internationalization are widely perceived that Turkey has been highly engaged in internationalization activities. On the contrary of these reports, some research and studies claims that Turkish higher education does not have a specified strategy for internationalization or for foreign students (Çetinsaya, 2014; Ministry of Development, 2015; Şeremet, 2015).

Student mobility in higher education is mostly connected to the Erasmus program which is the largest scheme of temporary mobility within Europe. Student mobility has spread considerably as a result of Erasmus program in 1987 (Rivza \& Teichler, 2007). However there are two other programs which offer exchange opportunity to students in higher education. One of these programs is Farabi exchange program which gives opportunity to students or academic members to continue their educational activities at a nationwide higher education institution instead of their own institutions for one or two terms. Mevlana exchange program is the second education program that enables student and academic personnel exchange between the higher education institutions inside and outside Turkey.

Incoming and outgoing students via exchange programs are considered to be an indicator to evaluate the extent of mobility. For this reason, the study aims to discuss internationalization in higher education and review of the present status of student mobility in higher education in Turkey. The study will provide a picture of internationalizing and mobility in higher education in Turkey to address strategic questions related to the future of higher education in Turkey, and to discuss in detail with the aim of shedding light on new planning.

\section{Method}

The research is as a descriptive study and used secondary data received from Council of Higher Education (CoHE) published on the web site, http://www.yok.gov.tr/ as well as international documents and reports. With the data percentage and frequency values are calculated and given via charts and graphs. 


\section{Findings}

Figure 1. shows the proportion of international/foreign students in tertiary education in European Union countries. Year of references for international/foreign student data is 2012.

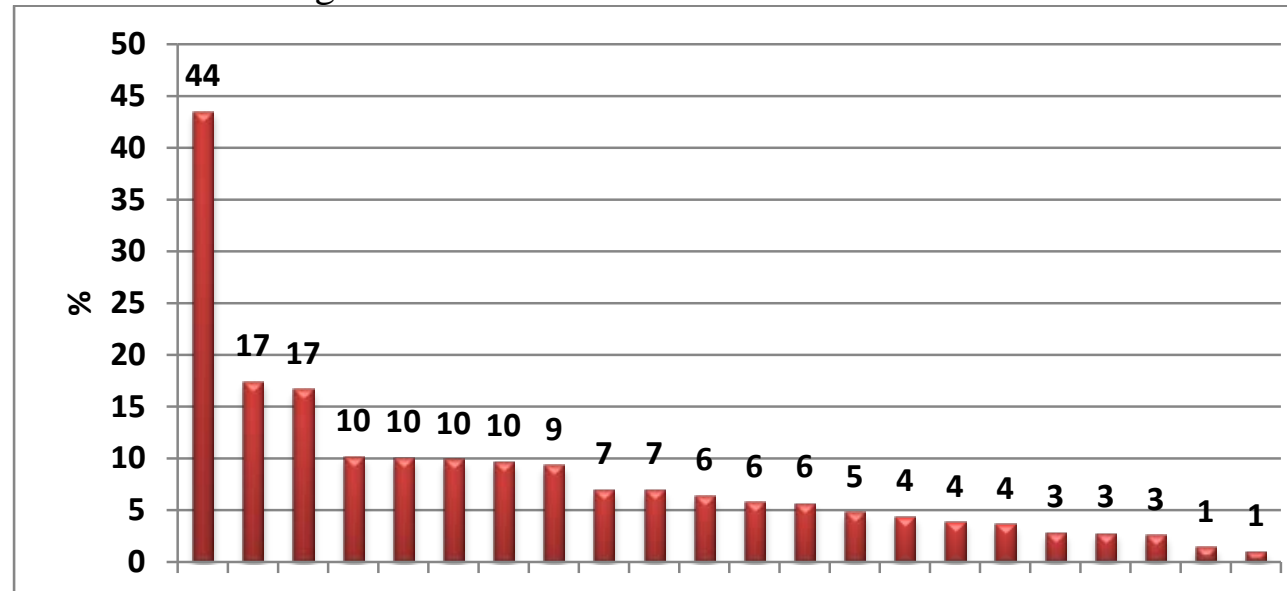

LU UK AT NL DK BE FR CZ FI DE IE SE HU SK IT PT LV EE ES SI PL TR

Fig. 1. Total International/Foreign Students at Tertiary Education in European Union Countries in 2012 (\%)

Source: OECD. (2015). Education at a Glance. Table C4.1. OECD Publishing.

*The students in Turkey, Italy and Czech Republic are defined as foreign students.

Luxembourg has the highest proportion and $44 \%$ of all students in tertiary education in Luxembourg are international students. $17 \%$ in United Kingdom, Switzerland and Austria are international students of all students in tertiary education. Turkey is far behind the EU countries average and has the lowest share of foreign students in tertiary education in most European Union countries. Just $1 \%$ of all students in tertiary education in Turkey are not Turkish students, are foreign students. Poland like Turkey has also the lowest share of international or foreign students in tertiary education. Slovenia, Spain and Estonia with 3\% international students have the nearest share with Turkey in European Union countries.

Figure 2 shows the proportion of foreign students in Turkey by nationality. The reference year of data is 2014/2015. The figure does not show the countries having the rates below $1 \%$ of foreign students in tertiary education. 


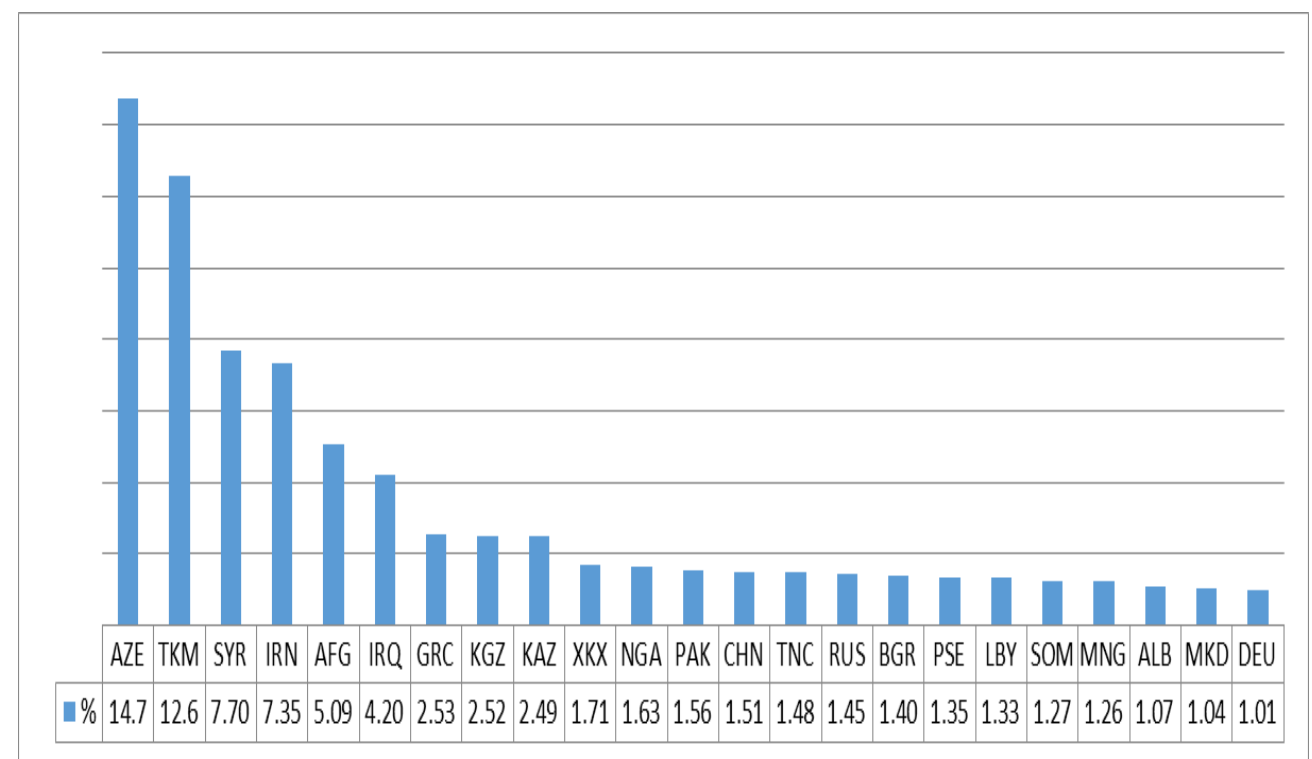

Fig. 2. Share of Foreign Students in Turkey by Nationality, 2014/2015 Source: Compiled by Council of Higher Education data

*International country codes are used.

The highest rate, $14.7 \%$ of all foreign students in tertiary education in Turkey come from Azerbaijan, This rate followed by Turkmenistan with the rate of $12.6 \%$. $7.70 \%$ foreign students come from Syria, $7.35 \%$ from Iran, $5.09 \%$ from Afghanistan and $4.20 \%$ from Iraq. 1\% of foreign students are from Germany, Makedonia, Albania, Mongolia and Somalia. The proportion of foreign students coming from Ukraine, Egypt, Bosnia and Hercegovina, United States of America, Indonesia and Serbia is below 1\%. The figure indicates that foreign students mostly come from non-European Union countries.

Share of foreign students by universities in Turkey is given in Figure 3. The figure shows just top universities having the highest share of foreign students in Turkey. 


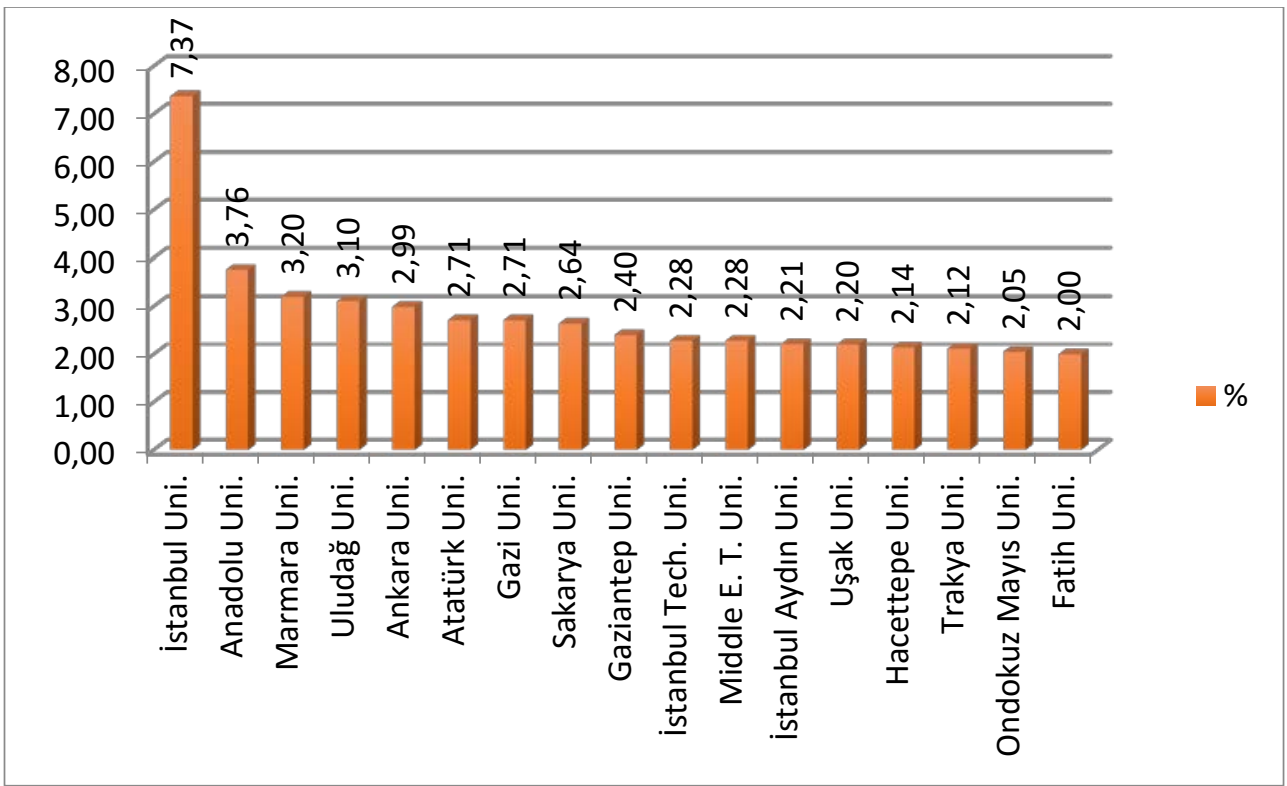

Fig. 3. Share of Foreign Students by Universities in Turkey, 2014/2015. Source: Compiled by Council of Higher Education data

İstanbul University has the highest share of foreign students in Turkey and \%7.37 of foreign students in tertiary education is in İstanbul University. İstanbul University is followed by Anadolu University (3.76), Marmara University (3.20), Uludağ University (3.10) and Ankara University (\%2.99). This shows that state universities are in top having the highest proportion of foreign students in Turkey. The other universities which have the share of foreign students below $\% 2$ are not shown in this figure.

Share of foreign students by level of tertiary education in Turkey is presented in Table 4. The reference year of data is 2014/2015.

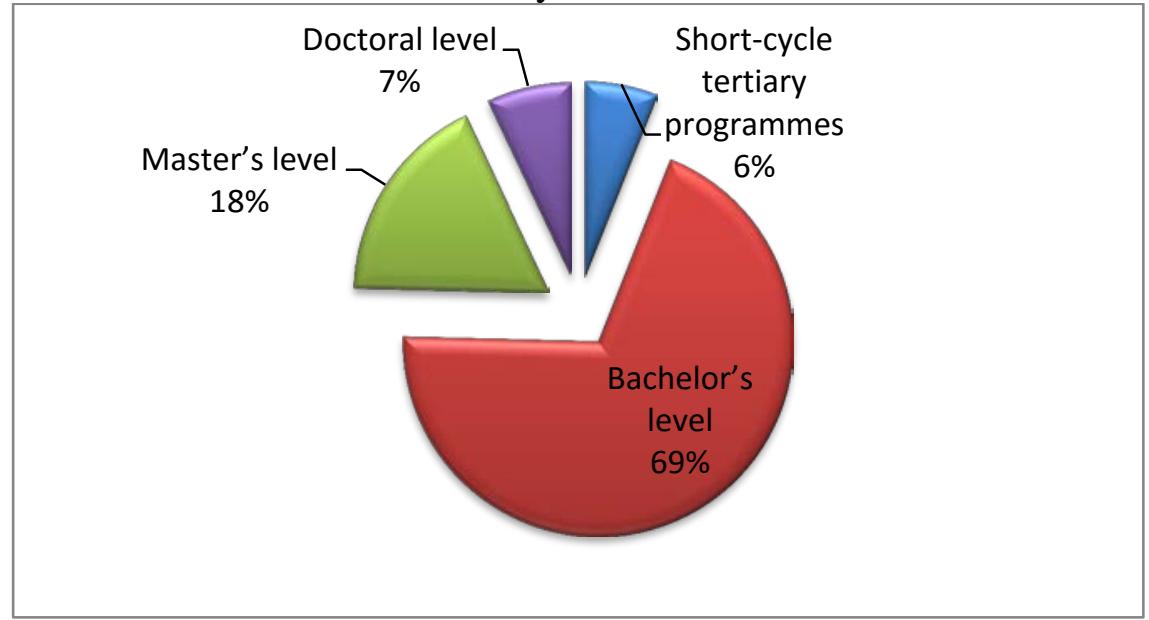

Fig. 4. Share of Foreign Students by Level of Tertiary Education in Turkey, 2014/2015

Source: Compiled by Council of Higher Education data 
Total number of foreign students in tertiary education in Turkey is 72178 in the year of $2014 / 2015$. 69\% of these foreign students are at bachelor's level; $18 \%$ of them at master's level; $7 \%$ and $6 \%$ of them are at doctoral level and short-cycle tertiary programs respectively.

Distribution of foreign students enrolled in tertiary programs in Turkey, by field of education is shown in Figure 5, with the reference year of 2013.

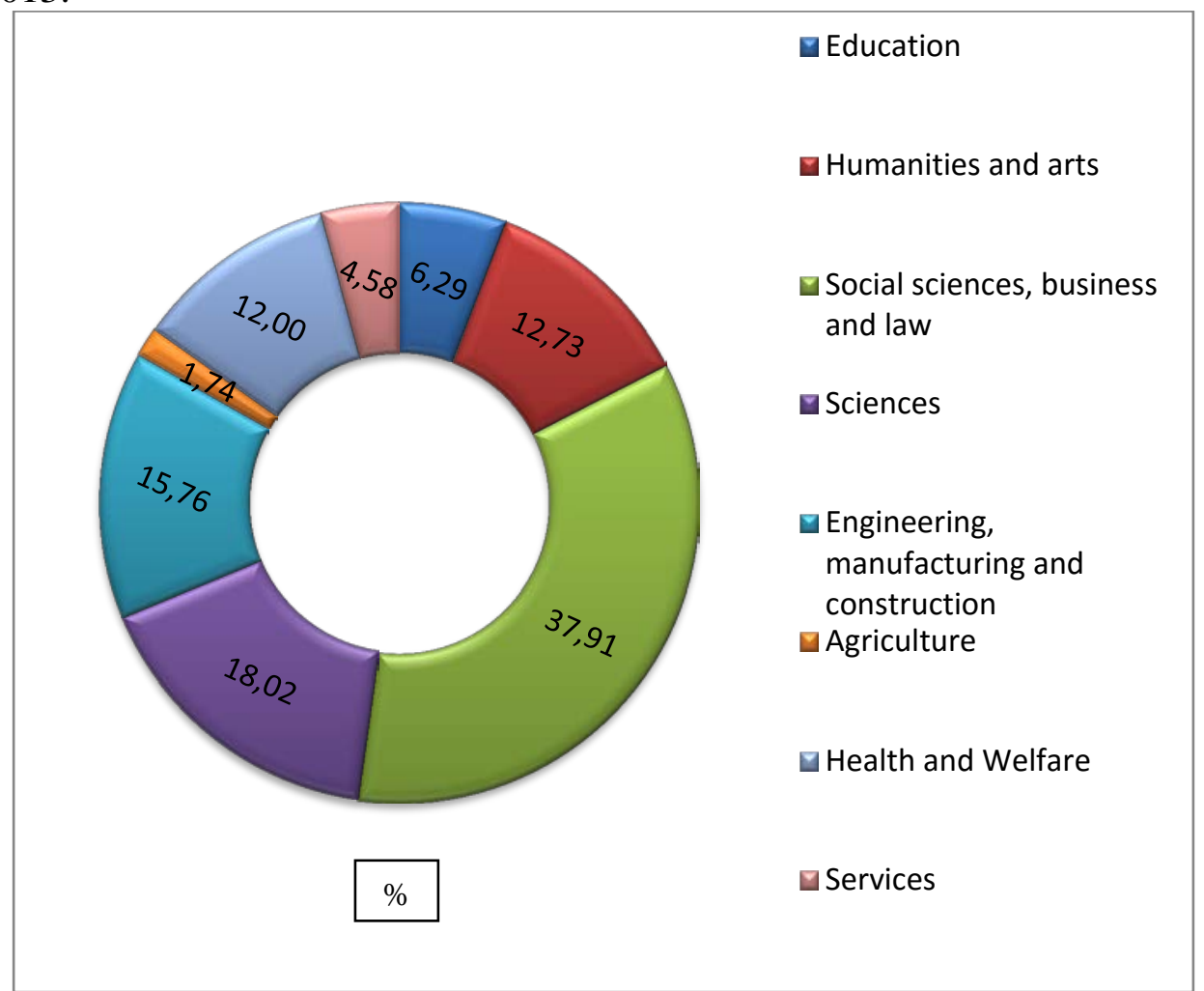

Fig. 5. Distribution of foreign students enrolled in tertiary programs in Turkey, by field of education.

Source: OECD. (2015). Education at a Glance. Table C4.2. OECD Publishing.

In Turkey, 37.91\% of all foreign students in tertiary education study at social sciences, business and law. This field of education is followed by sciences (\%18.02), engineering, manufacturing and construction (15.76) and humanities and arts (12.73). The distribution of foreign students in agriculture is the lowest rate. Agriculture (1.74) and services (\%4.58) are the least preferred tertiary programs by foreign students coming to Turkey.

Figure 5. presents the share of Erasmus outgoing students and Figure 6. shows the share of Erasmus incoming students with the reference year of 2014/2015. 


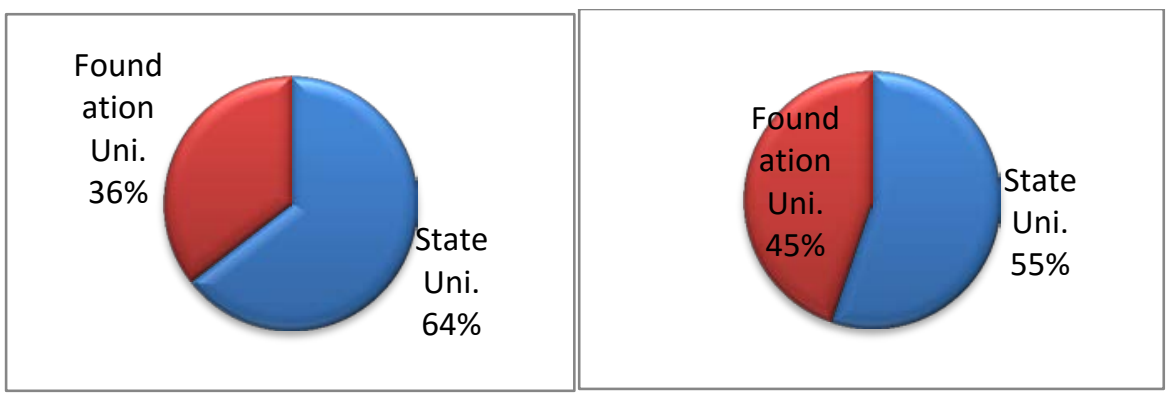

Fig. 5. Erasmus Outgoing

Fig. 6. Erasmus Incoming Source: Compiled by Council of Higher Education data

Total number of Erasmus outgoing students is 2517 and 64\% of these students are from state universities and 36\% of these Erasmus outgoing students are from foundation universities. On the other hand total number of Erasmus incoming students is 4249 and 55\% from state university and 45\% from foundation universities. It is perhaps more surprising that number of Erasmus incoming students is much more than the number of Erasmus outgoing students. Total number of Erasmus outgoing and incoming students in tertiary education is considerably low.

The share of incoming/outgoing mobility students at tertiary education in Turkey with the reference year of 2014/2015 is given in Figure 7. Erasmus and Mevlana incoming mobility refers to students that moved to Turkey in order to study whereas Farabi incoming students refer to students that moved to a specified university to study. Erasmus and Mevlana outgoing students are defined as the ones who moved out of Turkey in order to study and Farabi outgoing refers to the students that moved out of their university in order to study.

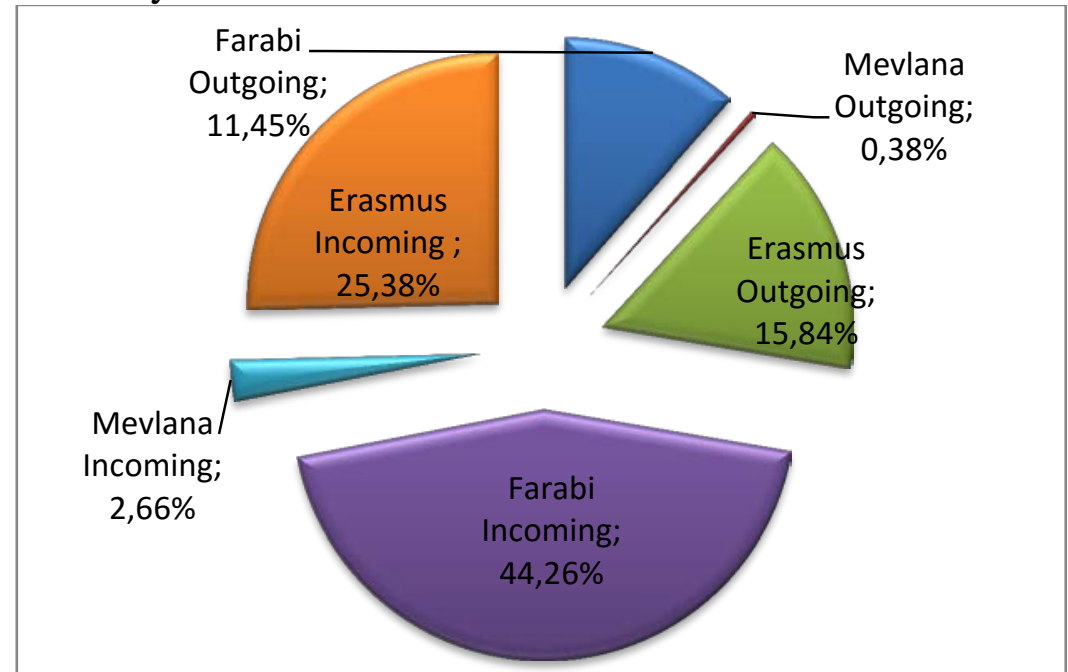

Fig. 7. Share of Incoming/Outgoing Mobility Students at Tertiary Education in Turkey, 2014/2015 Source: Compiled by Council of Higher Education data 
Total number of mobility students in Turkey in 2014/2015 is 16793. Approximately $41 \%$ of these mobility students are Erasmus mobility students and \%3.05 of these students came to Turkey via Mevlana Exchange Program whereas \%55.72 of these students prefers Farabi exchange program. This indicates that most of the tertiary students in Turkey prefers national exchange program however the proportion of Erasmus mobility is remarkably high.

\section{Conclusion}

This study discussed student mobility under the theme of internationalization in Turkish higher education context.

From the present overview, some remarkable findings come clearly to the forefront:

$\checkmark \quad$ Students mostly originating from Asian countries prefer Turkey for higher education. European students rarely prefer studying in Turkey.

$\checkmark \quad$ State universities are in the top and have the highest proportion of foreign students in Turkey.

$\checkmark \quad$ Most foreign students in Turkey are at bachelor's level.

$\checkmark \quad$ It is perhaps more surprising that number of Erasmus incoming students is much more than the number of Erasmus outgoing students. There is an imbalance between incoming and outgoing students in Turkey.

$\checkmark \quad$ Erasmus exchange students account nearly half of all mobility students in Turkey.

$\checkmark \quad$ Foreign students in Turkey prefer mostly studying at social sciences, business and law in tertiary education.

Turkey has not progressed much and filled the commitment declared at the EHEA Ministerial Conference in Bucharest in 2012. It is not possible at that moment to report accurately that higher education in Turkey is internationalized enough. There appears a need for much progress in Turkey in terms of mobility enhancement. Turkey has the lowest share of foreign students in Europe. To remove obstacles to student mobility was one of the implicit objectives of the Bologna Declaration however the study improves that little progress has been made on internationalizing in higher education in Turkey when compared to European Union countries. The reflection of the internationalization in Turkey has been superficial and there is certainly a need for a policy for attracting more foreign students.

Complexity of internationalization raises various challenges in Turkey. While Turkish higher education system is aware of the requirements set out in the Bologna Process, initiatives still seem to be restricted. It seems to be quite obvious that Turkey lacked a clear strategy and measures to tackle known obstacles to mobility. Turkish higher education must be responsive and orchestrate all of the factors related to mobility consistently 
in order to reap the benefits of internationalization as well as mange the ricks. It is likely that this low rate of mobility in Turkey is caused by so many reasons. To start with, possible reasons of the obstacle for student mobility should be defined and then national and institutional strategies with concrete aims of progress in mobility should be developed. Internationalization strategies also should involve the promotion of international training programs and teaching processes and should suggest opportunities of international education to the students who choose studies in Turkey.

\section{References:}

Aittola, H., Kiviniemi, U., Honkimaki, S., Muhonen, R., Huusko, M., \& Ursin, J. (2009). The Bologna process and internationalization-consequences for Italian academic life. Higher Education in Europe, 34(3-4), 303-312.

Atlbach, P., Reisberg, L., \& Rumbley, L. (2009). Trends in global higher education, tracking an academic revolution. Boston: Center for International Higher Education, Boston College.

Çetinsaya, G. (2014). Büyüme, kalite, uluslararasılaşma: Türkiye Yüksekögrretimi için bir yol haritası. Ankara: ükseköğretim Kurumu. Available at https://forum.yok.gov.tr/docs/ YolHaritasi.pdf Accessed on 10 March, 2016.

De Wit, H. (2010). Internationalization of higher education in Europe and its assessment, trends and issues. Den Haag: Nederlans-Vlaamse Accreditatieorganisatie.

Eurydice, 2015. The European higher education area in 2015: Bologna process implementation report. Luxembourg: Publications Office of the European Union.

Frolich, N., \& Amelia V. (2005). Competition, cooperation, consequences and choices in selected European countries, In B. Khem and H. de Wit (eds.), Internationalisation in higher education: European responses to the global perspective. Amsterdam: European Association for International Education and the European Higher Education Society (EAIR).

Henard, F., Diamond, L., \& Roseveare, D. (2012). Approaches to internationalization and their implications for strategic management and institutional practice, a guide for higher education institutions. Paris: OECD Publishing.

Karveliene, R. (2014). The Bologna Process and the features of implementation of the internationalization of higher education in Lithuania. Social Research, 2(35), 53-65.

Kehm, B. M. and Teichler, U. Research on internationalisation in higher education. Journal of Studies in International Education, 113-4 (2007): 260-273. 
Knight, J. (2003). Updating the definition of internationalization. International Higher Education, Fall (33), pp. 2-3.

London Communiqué. (2007). Towards the European higher education area: responding to challenges in a globalized world. Available at http://sefi.be/wpcontent/uploads/London\%20Communiqu\%C3\%A9\%2018M ay071.pdf Accessed on 10 March, 2016.

Ministry of Development. (2015). Yükseköğretimin uluslararasılaşması çerçevesinde Türk üniversitelerinin uluslararası öğrenciler için çekim merkezi haline getirilmesi. Ankara: Ministry of Development.

OECD (2015), Education at a Glance 2015: OECD Indicators. Paris: OECD Publishing. Available at http://dx.doi.org/10.1787/eag-2015-en Accessed on 5 March, 2016.

Rivza, B. and Teıchler, U. (2007). The Changing Role of Student Mobility, Higher Education Policy, 20(4), 457-475.

Şeremet, M. (2015). A comparative approach to Turkey and England higher education: the internationalism policy. Journal of Higher Education and Science, 5(1), 27-31.

Teichler U.,( 2009). Internationalisation of higher education: European experiences. Asia Pacific Education Revision, 10, 93-106 DOI 10.1007/s12564-009-9002-7

Wächter, B. (2008). Mobility and internationalisation in the European Higher Education Area., In Kelo, M. (ed.), Beyond 2010: priorities and challenges for higher education in the next decade. Bonn: Lemmens. 